\title{
Governance in the Field of Public and Gender Policies
}

\author{
David Pérez-Jorge1, Yolanda Márquez Domínguez¹, Milagros de la Rosa Hormiga², \\ Lara Pérez Martín33, María Sandra Marrero Morales4 \\ ${ }^{1}$ Department of Didactics and Educational Research, Faculty of Education, Universidad de La Laguna, San Cristóbal \\ de La Laguna, Spain \\ ${ }^{2}$ Nursing Department, Universidad de La Laguna, San Cristóbal de La Laguna, Spain \\ ${ }^{3}$ Department of Didactics and Educational Research, Universidad de la Laguna, San Cristóbal de La Laguna, Spain \\ ${ }^{4}$ Faculty of Health Sciences, Universidad de Las Palmas de Gran Canaria, Las Palmas de Gran Canaria, Spain \\ Email: dpjorge@ull.edu.es, marquezdominguez.yolanda@gmail.com, cloehormiga@gmail.com, \\ larapemar@gmail.com, sandra.marrero@ulpgc.es
}

Received 21 April 2015; accepted 5 July 2015; published 8 July 2015

Copyright (C) 2015 by authors and Scientific Research Publishing Inc. This work is licensed under the Creative Commons Attribution International License (CC BY). http://creativecommons.org/licenses/by/4.0/

(c) (i) Open Access

\section{Abstract}

Governance is a modern procedure in the task of governing which is performed through dialogue, negotiation and elucidation of goals, strengthened by an effective political communication with the different actors involved, who come from public or private sectors or from civil society, positioning themselves in the development process of public policy. As Bassols (Bassols, 2011: p. 16) states, "it is a technique of power that is related to the act of affecting and being affected, if we think of it as a Faucaultian version". Therefore, governance processes should be regarded as a means towards social transformation and, in particular, towards the transformation of social systems of gender roles. This form of democratic governance would be expressed through institutional changes or, in other words, through changes of the rules and regulations which organize the relationships among the different actors or partners in different settings, especially those relationships between the state and civil society, and those established among the state, market and family. In this sense, changes would open up new opportunities to transform gender roles assessing the implications of public policies for both men and women. This would include legislation and policies in all areas and levels. Therefore, the fact of introducing an approach based on gender in the processes of governance appears to be a strategy to integrate topics of interest and experiences of women and men as an integral dimension of the design, implementation and evaluation of policies in the political, economic and social sphere, to benefit both men and women. Thus, inequality is not perpetuated.

\section{Keywords}

Governance, Public Policies Management, Gender, Participation, Experience 


\section{Introduction}

Governance is a modern procedure in the task of governing which is performed through dialogue, negotiation and elucidation of goals, strengthened by an effective political communication. The different actors involved, who come from public or private sectors or from civil society, position themselves in the development process of public policy. Therefore, governance is a technique used for institutional purposes which are induced by means of consensus and not always provided by public policies accompanying it in public action. "It is a technique of power that is related to the act of affecting and being affected, if we think of it as a Faucaultian version (Bassols, 2011: p. 16)". In this sense, the processes of governance should be regarded as "a means towards social transformation and, in particular, towards the transformation of social systems of gender roles. Guzmán (2003: p. 13)"’.

As Guzmán (2003) points out, this form of democratic governance ${ }^{2}$ is expressed through institutional changes, that is to say, through changes of the rules and regulations which organize the relationships among the different actors or partners in different settings, especially those relationships between the state and civil society, and those established among the state, market and family. In this sense, changes in public policies would open up new opportunities to transform and favor gender power order as regards, for example, women's participation and the inclusion of the gender perspective in the processes of democratic governance, ensuring, therefore, their interests and requirements through appropriate and adapted instruments and mechanisms.

Reflection on the concept of "governance" responds to the regulatory concerns related to the search for new approaches which consider the increasing complexity of society, the different actors and the socio-political context. Although the ultimate goal is focused on reaching gender equality in the development process of a political action, looking for a transformation of the socio-political relationships from a participative perspective, the interests of the different actors should be highly considered. These interests frequently interfere with socio-political and cultural obstacles which prevent the development of a democratic system of governance which includes new approaches such as the gender perspective.

This article presents in broad terms an example of how democratic governance shows the way in which the combined efforts of governance bodies and civil society can play a key role in ensuring the initiation and implementation of political actions to transform relationships and gender dynamics.

\section{Concepts and Principles of an Effective and Efficient Governance}

Women are frequently excluded from decision making. However, their equitable participation in governance is an important challenge which implies recognition of the right to express their opinions and be heard. In a broader sense, it is a tool for social transformation. The decisions taken and the policies implemented by governance institutions at global, national and local levels contribute to create the perceptions related to the roles that women and men play in society. Moreover, they determine their access to rights and resources. The fact of involving people to participate in the definition of such policies and processes and influencing the institutions which produce them makes these more likely to be sensitive to the different needs and situations of both women and men and to contribute to gender equality.

The perspective of governance offers an opportunity to understand the state-society relations in a quite different framework from the usual one, placing emphasis on the consideration of government action as management of networks in which many public and private actors participate. The analysis of the literature related to

\footnotetext{
${ }^{1}$ We make reference to the genesis of the gender social system: “The gender system has structural (sexual division of work) and institutional (rules and regulations) roots which guide the distribution of resources and opportunities in society and particularly between men and women. It is also built symbolically. It is built upon, based on and reproduced in the conceptions, mentalities and collective perspectives. This system allows men to make use of a large range of resources-symbols, authority, recognition, objects and services-in different institutional fields.”

The concept of democratic governance makes reference to the change of institutions. Nevertheless, the social system of gender relations is basically an institutional order. It is made up of a field of rules and conventions which crystallize certain conceptions and mentalities and influence the perception that men and women have of themselves and their aspirations. These rules and conventions determine their access to opportunities and limit their possible field of choice. This system overlaps with other institutional systems. Therefore, the modification of any of them (family, economy, politics or culture) affects both gender power order and the changes in the system of gender relations.

${ }^{2}(. .$.$) Concern about democratic governance arises in this context of important economic, social and cultural transformations. The effects of$ globalization, the market-oriented economic reforms, the configuration of the most distinct and complex societies, the diversification of the interests of citizens, together with the tendency to participate in public issues multiply the demands addressed to the State, which is unable to respond because of the inadequacy of its rules, regulations, institutions and limited resources.
} 
governance has been widely discussed by many researchers from different disciplines. These analyses offer the possibility to question power relationships in different settings both public and private at all structural levels. Some studies on governance place the exercise of power beyond the area of the rule of law and extend it to the social and economic actors which are developed in civil society ${ }^{3}$.

Cabrero (2005), when dealing with the topic of local management in modern society, prefers to use a concept with a greater analytical coverage. He refers to public action as a "laboratory for studying" because the governance perspective has to be included not only for its possible fissures and disruptions, but also for the agreements among the different groups involved. Thus, in the governance approach, harmony dominates over conflict. Therefore, such conflict is expressed in a particularly positive mood according to the results obtained. Consequently, he takes the decision to adopt "a policy which achieves integration through consensus" (Cabrero, 2006: p. 24). Nevertheless, resistances will be present in governance exercises or in other forms of public action. Actually, in order to make agreements operational and effective, reforms in the institutional design of public bodies of government are needed. From a Faucaultian perspective, attention should be focused on an approach based on the types of "individualities" which appear in a specific society (Spanish, Brazilian or Mexican society). Each society is shaped by cultural patterns of life, by ways of relating with the exercise of power, its views on citizen participation, business and politics.

The concept of governance ${ }^{4}$ is not new and aims at the process of decision making and its implementation. Governance can be used in different contexts such as international, national and local governance entities. In fact, according to Brody (2009), many agencies and organizations consider that an efficient governance is the way to achieve goals which include the decrease of poverty and more equitable, democratic and corruption-free societies. Some of them consider that economic growth and efficiency are two important elements to achieve these final objectives. Governance should promote social justice and gender equality, apart from promoting the achievement of all citizen's rights. Moreover, these different actors evaluate the effectiveness of good governance basing on the level of accountability, transparency, inclusion and sensitivity of governance institutions towards its citizens. If these principles are defined, applied and measured in a way that reflects gender-related considerations, they can improve the performance of governance institutions. For instance, inclusive governance processes which promote a significant participation of both women and men are likely to result in programs which satisfy the needs of both sexes. This fact increases, therefore, its efficacy.

Like Annan (1998), we understand as a good public management the creation of political, legal and administrative institutions which work properly and account for the actions they perform. These actions have to be considered as legitimate by citizens and they also have to let them participate in decision-making processes which affect their lives and let them guide their future.

Good governance is being used over all by international organizations and agencies in developing countries. This conception often clashes with the interests of contributors, and in some cases, it may be detrimental to a good governance, because, in many cases, it conditions the flow of assistance and loans and the fact of introducing good governance reforms. In summary, we can state that there are differences related to what is considered as a good or effective governance and the ways it should be assessed.

Government is one of the actors in governance. Others actors involved in governance vary depending on the level of government which is being discussed. In rural areas, for example, it can include other actors such as farmers associations, cooperatives, NGOs, research institutions, religious leaders, financial institutions, political parties, the army, etc. The situation in urban areas is much more complex. Figure 1 shows the interconnections established among the different actors involved in the urban governance. At a national level, apart from the actors mentioned before, mass media, pressure groups, international donors or contributors, multinational companies, etc., can play an important role in or influence the decision making.

\footnotetext{
3“Civil Society” refers to the field of non-coercive collective action related to shared interests, purposes and values. (...) In general, civil society is made up of different settings, actors and institutional forms which vary depending on their degree of formality, autonomy and power. Civil Society is usually formed by registered charitable organizations, non-governmental development organizations, community organizations, women's organizations, faith-based organizations, professional associations, trade unions, self-help groups, social movements, business associations, coalitions and advocacy groups.

${ }^{4}$ Definition of governance by ESCAP: Economic and Social Commission for Asia and the Pacific. The original definition: "The concept of 'governance' is not new. It is as old as human civilization. Simply put 'governance' means: the process of decision-making and the process by which decisions are implemented or not implemented). Governance can be used in several contexts such as corporate governance, international governance, national governance and local governance.”
} 
"GOBERNANZA, O

MALA GOBERNANZA"
The Urban Elite:

-Shape the city formally and informally -Is well organized

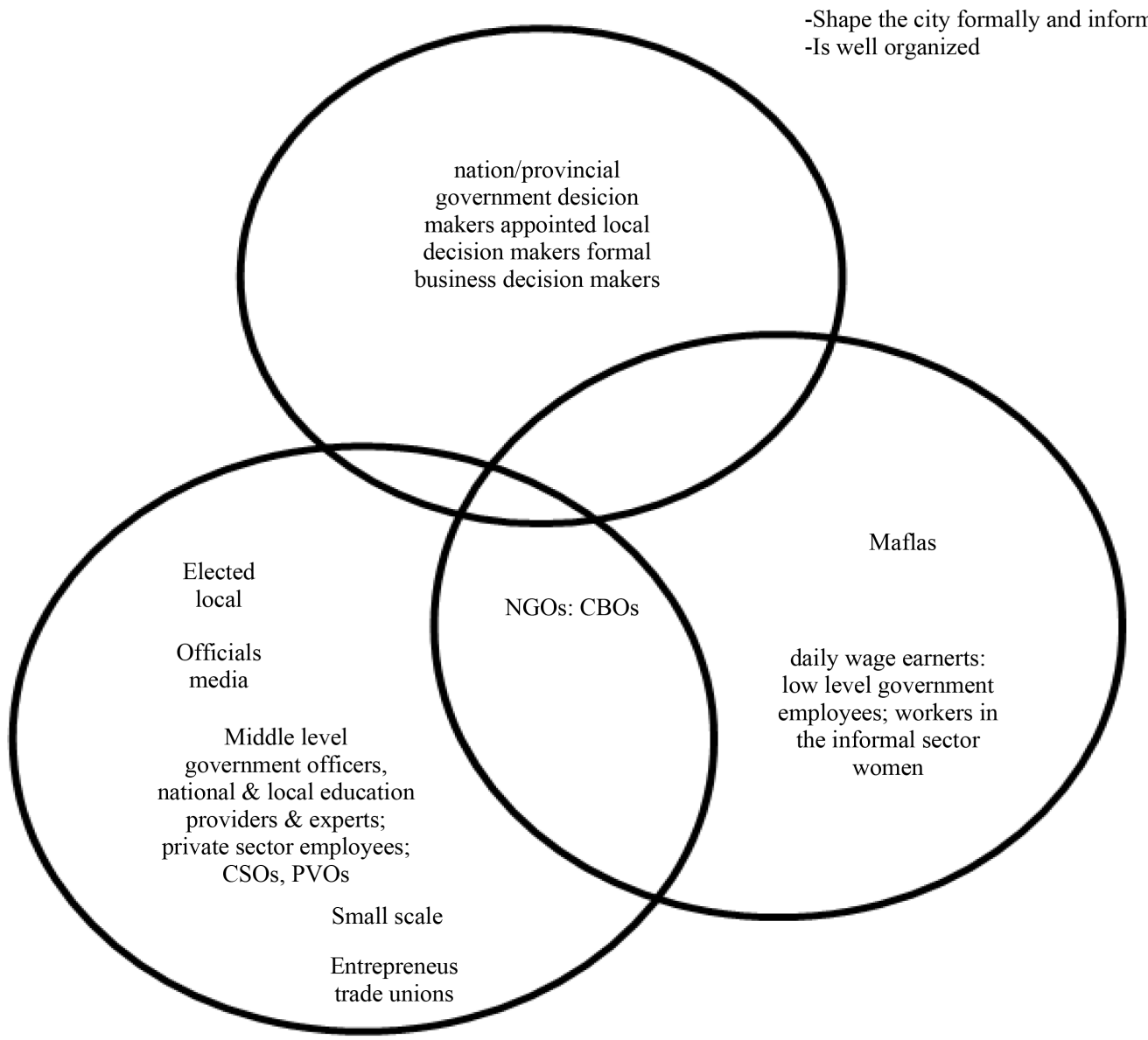

The urban middle class:

\section{uninformed}

uninferested

disorganized

but has the greastest potential to bring about the change
The urban poor:

-suffer the most

-are exploited

-but beginning to get organized
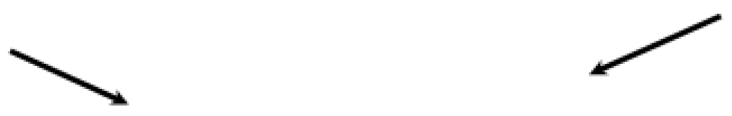

Must be strengthened, activated and given space so as to empower them

\section{Figure 1. Source ${ }^{5}$ : ESCAP: Economic and Social Commission for Asia and the Pacific.}

\section{Good Governance}

A "good" or "effective" governance refers to the quality of decision-making processes according to several principles ${ }^{6}$ of governance: participation, consensus, responsibility, transparency, efficacy and efficiency, equity and inclusion, and the rule of law. This is a way for assuring that corruption is reduced to a minimum, options related to minorities are taken into account and the voices of the most vulnerable in society are heard in deci-

\footnotetext{
${ }^{5}$ Graphics show a comparison between "Bad Governance" and "Good Governance”.

${ }^{6}$ The principles of governance tend to be gender blind in the sense that they do not frequently reflect the different needs, roles and experiences of women and men.
} 
sion-making processes. Moreover, it is sensitive to present and future needs of society.

Participation of both women and men constitutes the cornerstone of good governance. Participation can be direct or through legitimate intermediate institutions. It is of crucial importance to point out that representative democracy does not necessarily mean that the concerns of the most vulnerable people in society have to be taken into account in decision-making. There must be an informed and organized participation.

Good governance requires an impartial fulfillment of fair legal frameworks. Therefore, it is necessary to have a full protection of human rights, in particular, minority rights. Impartial law enforcement requires an independent judicial system and an impartial and incorruptible police service. In this sense, transparency is a key cornerstone of good governance. Citizens ${ }^{7}$ should "see through" the functioning of governance institutions. This fact means that information has to be available to them free of charge and they should not be prevented from looking for and sharing information. See Figure 2.

Good governance requires that institutions and their processes serve all stakeholders within a reasonable timeframe. There are many actors and many points of view in a society. Therefore, good governance must be able to act in the mediation of a broad range of interests to reach a broad consensus in society taking into account the best interest in the whole community and the different ways to reach it. A long-term perspective is needed to make a reality of a sustainable human development and to define the ways to achieve the objectives of such development. This can only result from an understanding of the historical, cultural and social contexts of a society or community which is governed taking into account this perspective.

Welfare society depends on the fact that all its members find interest in it and do not feel excluded from it. This situation requires that all groups, especially those most vulnerable, have the opportunity to improve or maintain their social welfare. Therefore, a good government has to guarantee the processes of democratic participation and its institutions have to produce results which satisfy the needs of all social collectives. This concept of efficiency in the context of a good governance will also promote the sustainable use of the resources of civil society.

According to Demetriades (2009), accountability is a key cornerstone of good governance, an act of social responsibility, not only from governance institutions but also from the private sector and civil society organizations. These must be responsible to those who will be affected by their actions or decisions.

We have to take into account that good governance is very difficult to achieve. Few countries have achieved good governance. However, in order to ensure the sustainable human development, it is necessary to take measures to progress towards this ideal with the aim of making it a reality.

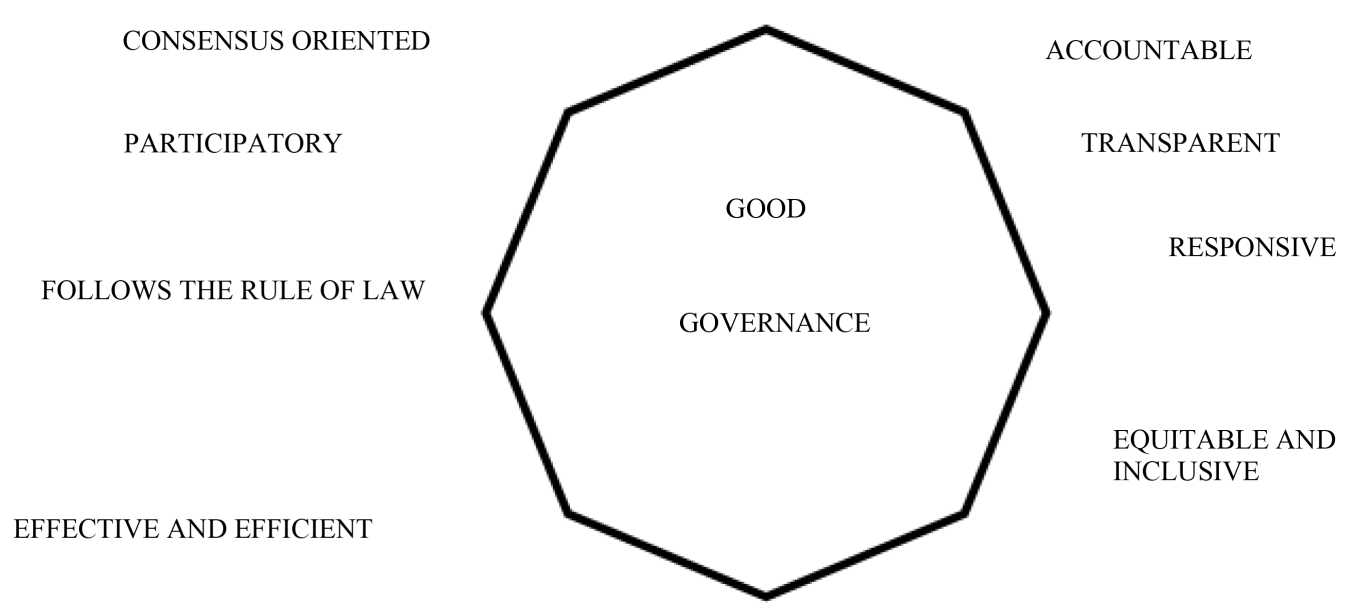

Figure 2. Source: ESCAP: Economic and Social Commission for Asia and the Pacific.

\footnotetext{
${ }^{7}$ The simplest meaning of "citizenship” refers to the condition of being a member of a community or a particular political state.

Most of the definitions of governance consider citizens as stakeholders in decision-making processes, that is to say, as people who share interests related to the functioning of these processes and what they achieve. Some interpretations of governance associate the notion of citizenship particularly to the fulfillment of the rights of poor and marginalized people, women included. Feminists and activists who struggle for women's rights have attempted to rethink citizenship from a gender perspective with the aim of demonstrating that fights for women's rights must be considered as struggles for citizenship which affect all people in society and must not be regarded as interests of "minorities” (Meer \& Sever, 2004).
} 


\section{Governance from a Gender Perspective}

As Hamadeh-Banerjee and Oquist (2000) state, until gender equality is reached ${ }^{8}$ in governance, women will not be able to achieve full equality with men in any field. They consider that the absence of women's voices in the definition of the most basic political instruments has promoted gender inequality. Women's participation is a key element in the field of public management. It implies better options, opportunities and the access of women to resources. This political and civic participation of women lets us observe women in and outside the traditional formal spaces of political exercise. In this sense, women have developed and develop at present much of their political action, (political action is seen as the activity in which power relationships are expressed and established, that is to say, the activity which enables us to speak about women's political participation in all areas of life. Kabir, 2003: p. 1), in informal political structures such as NGOs and social movements.

Therefore, it is not enough to increase in numbers women's participation in politics without the existence of a legislation to change the governance model and its policies. If we are not sensitive to recognize that the different needs, interests, priorities and responsibilities of both men and women deserve another consideration, apart from combating entrenched gender inequality, we have to admit that women's right to participate in decision-making processes must be a real fact.

This is an assertion which is not incompatible with women's equal participation in the access to and the exercise of decision-making. Substantive equality has been already defined in the Organic Law for effective equality between men and women (effective since 2007 in Spain). This implies a legal, substantive and effective equality in all areas of development. Nevertheless, it is necessary to incorporate the concepts of governance and gender which suggest a new government which introduces gender mainstreaming to identify great challenges in the new contexts of our societies, over all the power of citizens, considered as an exercise which facilitates people's access to civic, social, economic and cultural rights. Moreover, it questions and prevents the increase of inequality and poverty, considered as the main deficiencies in democracy.

A sensitive governance implies that women and men have to participate under equal conditions in the design and implementation of the processes to promote an increased representation of women in governance fields, eliminating discriminations and creating parities. Because of the fact that many women suffer a permanent exclusion in exercising their political rights due to their gender condition, it is necessary to institutionalize the gender perspective in governance bodies which ensure equality and non-discrimination based on gender, promoting the exercise of an active role in discussing democracy processes and tools.

To increase the number of women in policy-making positions would only lead us to a more equitable system of governance if their participation is ensured. This requires both a change in the roles that women and men play and the creation of an environment in which people can be considered and valued for their abilities and not for their gender or sexuality.

To sum up, governance from a gender perspective results in better options, opportunities, access to resources and a better quality of life, through governance policies and actions which challenge gender inequalities which remain deeply entrenched in society, and which are supported by strong accountability mechanisms in all governance institutions.

\section{Experience in Gender and Local Governance}

Advocating for a radical change in the governance model is not a practical strategy to achieve the inclusion of a gender governance, if we consider the experiences of governments which have a structure and philosophy different from that of westerns state models. For example, the ideological emphasis of the Chinese Communist Party on equality has been focused on women's rights in all policies of the party and on the establishment of the Ministry for women. China Women’s Federation, established in 1949, has played an active role in promoting gender-sensitive laws and maintaining in the agenda of the policies of the party an approach related to gender discrimination. This fact has been crucial and decisive to adopt laws to protect women and has also favoured the development of legislation to guarantee a life free from other forms of abuse for women (Howell, 1998).

In contrast, in fragile states the presence of a strong central government has been regarded as a key element in the creation of a gender sensitive bureaucratic culture and in the establishment of the principles of democratic governance, accountability and transparency. It has been also of crucial importance in the progressive or gradual

${ }^{8}$ PNUD: http://www.undp.org/governance/docs/Gender-Pub-21stcentury.pdf. 
introduction of governance mechanisms to facilitate the participation and voice of women in institutions and in the creation of gender sensitive policies ${ }^{9}$.

Nevertheless, the increase of decentralization of government functions is reinforcing the creation of local councils and other governance institutions in local and urban areas. These bodies are been given a greater power to respond to citizens' needs and priorities with the aim of providing better services. The flexibility and immediacy of this governance tool provides greater opportunities to citizens' participation and opens, furthermore, spaces for women and other groups which have been traditionally excluded from politics. The participation in the local government is a more usual practice in the local field than in the national one because "local eligibility criteria are less stringent and the local government is closer to women's sphere of life. It is easier to combine it with children care" (Evertzen, 2001: p. 3). However, the quality of women's participation is not ensured although women are involved in the local government and civic processes. The increasing emphasis on decentralization and the power or authority associated to local governing bodies can imply the existence of a greater interest in men's participation at a local level and a greater probability for women to be excluded, although quota systems have been established (Evertzen, 2001). There is no guarantee that local governance will be more sensitive to women's needs or interests. Actually, "it is frequently more difficult to create a distance between those institutions of the local government and the entrenched conventional social norms, which are patriarchal, due to the traditional authorities which protect them" (Beall, 2005: p. 10). Furthermore, there are cases in which there appear evidences of a greater and effective female participation in local governance. This fact must not prevent us from achieving that more women occupy leadership positions in executive powers. A lasting change has to be supported by the government at the state level. As an example, we can mention Panchayat as a model of local governance (assemblies or rural councils) in India. This system has set a precedent in the modification of the quota system to lead women to local political areas, ensuring, at the same time, a certain level of political representation of other disadvantaged groups, such as the low castes, also called "untouchables".

The Panchayat system of governance is made up of three levels: 1) villages; basic units known as panchayat (assembly or rural councils), 2) groups of villages and 3) districts.

In this system each village is responsible for their own issues, although villages are under the national government leadership. In 1976 there were some attempts to increase women's participation in local bodies through the introduction of nominal quotas. An important event took place in 1983, when the southern state of Karnataka reserved 25 percent of seats in the Panchayat for women. This fact led to the election of approximately 50 percent of women in 1987, and, for most of them, this was their first experience in politics. Other states followed this example and obtained similar results. Panchayat elections, held every five years, were called in the country in 1992 and reforms obliged to reserve 33 percent of seats for women, and also for low castes and tribes. This process has led to the election of more than 700.000 women.

According to Basu (2003), this experience was regarded as a positive example of women's influence within the Panchayat (from the "inside"). Women, who had participated actively in protests against large-scale fishing practices, made use of the Panchayat to demand the right to work. In Maharashtra, a group of women won the local elections replacing the opposition which was only made up by men. The reforms they introduced included amendments made to laws related to land and property rights which discriminate against women up to that time. On the other hand, with women's participation in these local councils, increased attention has been given to children's education and improvements of infrastructure and educational resources.

Participation in Panchayat has allowed women to fight against gender inequalities which are still deeply entrenched in society. For example, some areas have recognized that illiteracy and lack of formal education can prevent effective participation in public activities (Jayal, 2006). Women are starting to insist on their daughters' education before getting married. However, the presence of women in elected bodies does not guarantee a governance system with a great gender equality. Certainly, in some cases they can be elected to act as agents of the men in their families or they could not have the capacity to operate effectively in their positions. Moreover, they can deal with the intransigence of established circles of power, dominated by men, at village and districts levels (Vyasulu \& Vyasulu, 2000).

The processes of citizen participation and other processes in local governance are not always so inclusive and conscious of the concept of gender. Therefore, they should be evaluated to analyze and solve the main causes of exclusion. Women international organizations play an important facilitator and mediator role in the different le-

${ }^{9}$ (See Demetriades, 2009, Section 4.5, case study on a governance with a gender perspective in Sudan). 
vels of governance. However, these must examine their own internal governance practices and their notions about gender in order to be as efficient as possible in these roles.

Taking into account these considerations, the true change must begin with the conceptual bases of governance. It is of crucial importance to recognize the points of tension between notions and practices in governance, for example, in its capacity of decentralization and being, furthermore, more inclusive and conscious of the concept of gender and its importance. It is necessary that all governance institutions contribute to the creation of a public awareness. This involves demonstrating good practices and communicating effectively. Their messages must challenge the current perceptions of "common sense”. According to these perceptions, governance belongs to the field of men, who are far from the reality of ordinary people. Moreover, they should enable women everywhere to identify and claim their place in institutions and governance processes which are designed with them and not for them.

\section{Conclusion}

A gender sensitive governance implies a world with better options, opportunities, access to resources and life outcomes for women. This can be achieved through policies and strong accountability mechanisms which challenge gender inequalities deeply entrenched in society. Gender equality is one of the challenges in this century. Parity democracy has been of crucial importance in the emergence of the key role of women and in the failure of both the patriarchal system and the logic of the market. Nevertheless, nowadays there is still a long way to go. We must be constantly alert and reflect on the design of equality policies, trying to influence basically on the resolution of two aspects: the systematic gap between the official policy and its implementation and the limitation of gender issues in the institutional field, emphasizing the private sphere, which is also aimed at men.

Governance can only be efficient if it is based in the achievement of social justice and gender equality to promote a more efficient governance. Therefore, one of the challenges of modern governance is the transformation of those social relationships directed to a participatory management of public life and policy, taking into account the roles and interests of the different actors to face the political, cultural and social resistance which prevents the functioning of a governance system which includes new aspects such as gender equality.

This challenge suggests that the empowerment of groups and communities can negotiate with public institutions, articulating issues related to gender equality, respect for human rights and women's leadership. Therefore, it is necessary to rethink about the concept and practice of governance from an approach regarding gender, rights and capacity development. In this sense, some topics appear to be key: investment and public spending, the private sphere of the family, the necessary protection and respect for human rights, the informal and domestic work sector, flow of services such as those related to sexual and reproductive health, water, sanitation services, safety in towns, new forms of organization, women's networks and alliances.

\section{References}

Annan, K. (1998). Apoyo a la buena gestión pública. Memoria del Secretario General sobre la labor de la Organización (A/53/1), New York. http://www.un.org/spanish/docs/mem98.htm

Bassols, M., Mendoza, C. et al. (2011). Gobernanza: Teoría y prácticas colectivas. Anthopos. Universidad Autónoma Metropolitana-Iztapalapa, México. División de Ciencias Sociales y Humanidades.

Beall, J. (2005). Decentralizing Government and Centralizing Gender in Southern Africa: Lessons from the South African Experience [Descentralizando el gobierno y centralizando el género en el sur de África: Lecciones de la experiencia sudafricana]. Ginebra: Instituto de Investigación de las Naciones Unidas para el Desarrollo Social (UNRISD).

Brody, A. (2009). Gobernanza y Género. Informe General. BRIDGE.

Cabrero, E. (2005). Acción pública y desarrollo local. México: Fondo Cultura Económica.

Demetriades, J. (2009). Colección de recursos de apoyo. Canasta básica de BRIDGE sobre género y cuidados. Brighton: IDS.

Evertzen, A. (2001). Gender and Local Governance [Género y gobernanza local]. La Haya: Servicio Holandés de Cooperación al Desarrollo (SNV).

Guzmán, V. (2003). Gobernabilidad democrática y Género, una articulación posible. CEPAL.

Hamadeh-Banerjee, L., \& Oquist, P. (2000). “Overview”, Women’s Political Participation and Good Governance: 21st Century Challenges [“Sinopsis”, Participación política de las mujeres y buena gobernanza: Desafíos del siglo 21]. New York: PNUD. 
Howell, J. (1998). Civil Society and the State in China [La sociedad civil y el Estado en China]. In V. Randall, \& G. Waylen (Eds.), Gender, Politics and the State [El género, la política y el Estado]. London: Routledge.

http://dx.doi.org/10.4324/9780203004890_chapter_10

Jayal, N. G. (2006). Engendering Local Democracy: The Impact of Quotas for Women in India’s panchayats [Incorporando la perspectiva de género en la democracia local: El impacto de las cuotas para las mujeres en los concejos rurales de India]. Democratización, 13, 15-35. http://dx.doi.org/10.1080/13510340500378225

Kabir, F. (2003). Political Participation of Women in South Asia. DAWN.

Meer, S., \& Sever, C. (2004). Informe General. Canasta básica de BRIDGE sobre género y ciudadanía. Brighton: IDS.

Vyasulu, P., \& Vyasulu, V. (2000). Women in the Panchayat Raj: Grassroots Democracy in India [Las mujeres en los concejos rurales de India]. In Women's Political Participation and Good Governance: 21st Century Challenges [Participación política de las mujeres y buena gobernanza: Desafíos del siglo 21]. New York: PNUD.

\section{Notes}

Note 1: Gobernabilidad democrática y Género, una articulación posible. CEPAL, 2003, p. 13.

Note 2: Gobernabilidad democrática y Género, una articulación posible. CEPAL, 2003, p. 10.

Note 3: Centro para la Sociedad Civil de la Escuela de Economía de Londres:

http://www.lse.ac.uk/collections/CCS/introduction.htm.

Note 4: Brody, Alyson. Gobernanza y Género. Informe General. BRIDGE. 2009.

Note 7: Meer, S. \& Sever, C. (2004), “Informe general”, Canasta básica de BRIDGE sobre género y ciudadanía, Brighton: IDS, http://www.bridge.ids.ac.uk/reports_gend_CEP.html\#Citizenship.

Note 8: PNUD: http://www.undp.org/governance/docs/Gender-Pub-21stcentury.pdf.

Note 9: http://www.bridge.ids.ac.uk/reports gend_CEP.html\#Governance. 